\section{Leaching Fraction and Fertilization Effects on Growth of Three Woody Legumes Inoculated with Rhizobia}

\author{
William R. Graves, Sandra R. Anfinson, and Kathryn K. Lappegard \\ Department of Horticulture, Iowa State University, Ames, IA 50011-1100
}

Additional index words. Laburnum alpinum, Maackia amurensis, Wisteria sinensis, nitrogen fixation

\begin{abstract}
Scotch laburnum [Laburnum alpinum (Mill.) Bercht.], Amur maackia (Maackia amurensis Rupr. \& Maxim.), and Chinese wisteria [Wisteria sinensis (Sims) Sweet] were inoculated with compatible rhizobia and treated with leaching fractions $(\mathrm{LF})$ of $0,0.2$, and 0.4 using fertilizer solutions with 3.6 and $10.7 \mathrm{~mol} \mathrm{~N} / \mathrm{m}^{3}$ for 10 weeks. $\mathrm{LF}$ did not affect plant dry mass, leaf area, or stem length. Growth was higher among plants provided 10.7 mol $\mathrm{N} / \mathbf{m}^{3}$, but only plants provided $3.6 \mathrm{~mol} \mathrm{~N} / \mathrm{m}^{3}$ formed root nodules. We conclude that growth is not reduced by eliminating leaching during the first 10 weeks of seedling development, and that application of $10.7 \mathrm{~mol} \mathrm{~N} / \mathrm{m}^{3}$ prevents nodulation of these species.
\end{abstract}

Reducing leaching fractions (LF) minimizes irrigation runoff but may curtail growth of salt-sensitive plants, particularly if high fertilizer concentrations are applied (Ku and Hershey, 1992; Yelanich and Biernbaum, 1990, 1993). Inoculation with rhizobia might substitute for $\mathrm{N}$ applied during production of some crops, but effects of LF and $\mathrm{N}$ on root nodulation of many nursery crops are not known. Our objective was to determine the effect of $0,0.2$, and 0.4 LF imposed using solutions containing 3.6 and $10.7 \mathrm{~mol} \mathrm{~N} / \mathrm{m}^{3}$ on growth of Scotch laburnum, Amur maackia, and Chinese wisteria inoculated with rhizobia.

\section{Materials and Methods}

Scarified seeds of Scotch laburnum and Amur maackia were sown on 18 May 1993, and unscarified seeds of Chinese wisteria on 21 May, in flats with 1 perlite : 1 sphagnum peat (v/v). Flats were kept in a glasshouse with natural radiation and irrigated daily with tap water.

Twenty-four seedlings of each species were planted singly in $1840-\mathrm{ml}$ plastic pots $(15 \mathrm{~cm}$ in diameter) (Belden Plastics, St. Paul, Minn.) on 14 June (block 1) and 15 June (block 2) using a commercial medium (Fisons Special Blend \#1 Mix; Fisons, Warwick, N.Y.) of 5 sphagnum peat : 4 composted pine bark : 1 perlite (by volume). Plastic screen was placed over drainage holes to prevent loss of medium. Before planting, $550 \mathrm{ml}$ distilled water was

Received for publication 28 Feb. 1994. Accepted for publication 23 Sept. 1994. Support from the Program for Women in Science and Engineering at Iowa State Univ. is gratefully acknowledged. Journal paper no. J-15750 of the Iowa Agriculture and Home Economics Experiment Station, Ames. Project no. 3229. The cost of publishing this paper was defrayed in part by the payment of page charges. Under postal regulations, this paper therefore must be hereby marked advertisement solely to indicate this fact. applied to each pot three times, decreasing the electrical conductivity (EC) of leachate from $\approx 2.7$ to $\approx 0.7 \mathrm{dS} \cdot \mathrm{m}^{-1}$. While planting, $1.5 \mathrm{ml}$ of liquid rhizobial culture with $\approx 10^{8}$ cells $/ \mathrm{ml}$ (Batzli et al., 1992) was placed in each planting hole. For Amur maackia, USDA 4349 (Rhizobium Culture Collection, Beltsville, Md.) was used. Equal volumes of USDA 3104 and 3105 were used for Chinese wisteria. TAL 1262 (NifTAL, Univ. of Hawaii, Paia) was used for Scotch laburnum.

Pots were arranged on a glasshouse bench in a randomized complete-block design. Within both blocks, four pots with each species were assigned to a $3 \times 2$ factorial of treatments. There were three LF treatments $(0,0.2$, and 0.4 ) and two fertilizer solution treatments (3.6 and $10.7 \mathrm{~mol} \mathrm{~N} / \mathrm{m}^{3}$ ) prepared with tap water $\left(\mathrm{pH}=9.1, \mathrm{EC}=0.4 \mathrm{dS} \cdot \mathrm{m}^{-1}\right.$, alkalinity $=58$ mg.liter ${ }^{-1}$ ) and a commercial $21 \mathrm{~N}-2.2 \mathrm{P}-16.6 \mathrm{~K}$ fertilizer (Peters Excel All Purpose; GraceSierra, Milpitas, Calif.). Solution $\mathrm{pH}$ was adjusted to between 6.0 and 6.6 by adding sulfuric acid. After planting, pots were brought to container capacity by irrigating with $300 \mathrm{ml}$ of level. the appropriate solution. Initial mass of pots at container capacity was determined after they drained for $1 \mathrm{~h}$.

Irrigations were performed each Monday and Thursday (block 1) or Tuesday and Friday (block 2). The volume of solution to apply to achieve the proper LF was determined for each pot as described by $\mathrm{Ku}$ and Hershey (1992). Treatments were maintained for 10 weeks. Maximum radiation intensity during treatments was $510 \mu \mathrm{mol} \cdot \mathrm{m}^{-2} \cdot \mathrm{s}^{-1}(400-700$ $\mathrm{nm}$ ), and the air ranged from 18 to $34 \mathrm{C}$.

Plants were harvested on 23 (block 1) or 24 (block 2) Aug. Length of stems $\geq 3 \mathrm{~cm}$ long was measured. Leaf surface area was determined using a LI-COR 3100 area meter (LICOR, Lincoln, Neb.). EC of a complete vertical core sample of medium from pots with Chinese wisteria, the species that received the most irrigation solution, was estimated (Bunt, 1988). Roots were separated from the medium and assessed visually for nodulation. Dry mass of shoots and roots was determined after tissues were held at $67 \mathrm{C}$ for 2 days. The influence of LF, fertilizer, and their interaction on the dependent variables was evaluated by using analysis of variance. In no case was the interaction significant $(P \leq 0.05)$, so only means of main effects will be presented.

\section{Results and Discussion}

The total volume of solution applied to the three species to provide $3.6 \mathrm{~mol} \mathrm{~N} / \mathrm{m}^{3}$ ranged from (milliliters) 19,970 to 21,$410 ; 27,160$ to 29,730; and 35,650 to 42,050 for plants in the $0,0.2$, and $0.4 \mathrm{LF}$ treatments, respectively. For plants given $10.7 \mathrm{~mol} \mathrm{~N} / \mathrm{m}^{3}, 26,040$ to 28,340 $\mathrm{ml} ; 32,900$ to $34,390 \mathrm{ml}$; and 46,010 to 49,580 $\mathrm{ml}$ were applied to plants in the $0,0.2$, and 0.4 LF treatments, respectively. The actual LF (total volume of leachate/total volume applied) averaged over species and $\mathrm{N}$ treatments for plants in LF 0.2 and 0.4 was 0.12 and 0.33 , respectively. Using similar methods with florist crops, $\mathrm{Ku}$ and Hershey $(1991,1992)$ also found actual LF to be less than predicted LF. Differences between actual and predicted LF might be minimized by considering plant mass

Table 1. Influence of leaching fractions (LF) and rate of applied $\mathrm{N}$ on growth of containerized seedlings of Amur maackia, Scotch laburnum, and Chinese wisteria. LF values are means of 16 replicate plants at both $\mathrm{N}$ rates. Nitrogen rate values are means of 24 replications at three LF. LSD values are for the $P=0.05$

\begin{tabular}{|c|c|c|c|c|c|c|c|}
\hline \multirow{2}{*}{$\begin{array}{l}\text { Species and } \\
\text { dependent variable }\end{array}$} & \multicolumn{4}{|c|}{ Leaching fraction } & \multicolumn{3}{|c|}{$\mathrm{N}$ rate applied $\left(\mathrm{mol} \cdot \mathrm{m}^{-3}\right)$} \\
\hline & 0 & 0.2 & 0.4 & LSD & 3.6 & 10.7 & LSD \\
\hline \multicolumn{8}{|l|}{ Amur maackia } \\
\hline Root dry mass (g) & 0.9 & 0.8 & 0.9 & 0.2 & 0.6 & 1.2 & 0.2 \\
\hline Shoot dry mass (g) & 2.4 & 2.4 & 2.6 & 0.6 & 1.3 & 3.6 & 0.5 \\
\hline Leaf area $\left(\mathrm{cm}^{2}\right)$ & 416 & 478 & 499 & 132 & 253 & 676 & 108 \\
\hline Stem length $(\mathrm{cm})$ & 23.6 & 24.3 & 24.5 & 5.8 & 17.9 & 30.4 & 4.7 \\
\hline \multicolumn{8}{|l|}{ Scotch laburnum } \\
\hline Root dry mass (g) & 0.8 & 0.9 & 1.0 & 0.3 & 0.7 & 1.1 & 0.2 \\
\hline Shoot dry mass (g) & 2.0 & 2.4 & 2.5 & 0.8 & 1.2 & 3.3 & 0.7 \\
\hline Leaf area $\left(\mathrm{cm}^{2}\right)$ & 288 & 319 & 352 & 135 & 201 & 438 & 110 \\
\hline Stem length $(\mathrm{cm})$ & 29.0 & 32.1 & 30.1 & 9.7 & 19.8 & 41.0 & 7.9 \\
\hline \multicolumn{8}{|l|}{ Chinese wisteria } \\
\hline Root dry mass (g) & 1.3 & 1.4 & 1.6 & 0.4 & 1.0 & 1.9 & 0.4 \\
\hline Shoot dry mass (g) & 3.9 & 3.8 & 4.2 & 1.1 & 1.7 & 6.1 & 0.9 \\
\hline Leaf area $\left(\mathrm{cm}^{2}\right)$ & 770 & 732 & 908 & 214 & 247 & 1359 & 175 \\
\hline Stem length $(\mathrm{cm})$ & 33.7 & 31.6 & 31.6 & 12.4 & 22.7 & 41.9 & 10.1 \\
\hline
\end{tabular}


when determining the volume of solution to apply at each irrigation ( $\mathrm{Ku}$ and Hershey, 1991).

LF did not affect growth of the three species (Table 1). Dry mass, leaf area, and stem length for plants given $10.7 \mathrm{~mol} \mathrm{~N} / \mathrm{m}^{3} \mathrm{ex}$ ceeded those for plants given $3.6 \mathrm{~mol} \mathrm{~N} / \mathrm{m}^{3}$ (Table 1). Mean ( $\pm \mathrm{SE}) \mathrm{EC}$ of the medium was $1.2(0.2), 1.2(0.1)$, and $1.1(0.2) \mathrm{dS} \cdot \mathrm{m}^{-1}$ in the $0,0.2$, and $0.4 \mathrm{LF}$ treatments, respectively, when maintained with solution containing 3.6 $\mathrm{mol} \mathrm{N} / \mathrm{m}^{3}$. Mean $( \pm \mathrm{SE})$ EC was $2.6(0.1), 2.2$ (0.2), and $1.4(0.2) \mathrm{dS} \cdot \mathrm{m}^{-1}$ at $\mathrm{LF} 0,0.2$, and 0.4 , respectively, using solution with $10.7 \mathrm{~mol} \mathrm{~N} /$ $\mathrm{m}^{3}$. Plants given $3.6 \mathrm{~mol} \mathrm{~N} / \mathrm{m}^{3}$ nodulated profusely, and LF did not appear to influence nodule quantity or size. Plants given $10.7 \mathrm{~mol}$ $\mathrm{N} / \mathrm{m}^{3}$ lacked nodules.

Leaching can be eliminated for 10 weeks without affecting growth of Amur maackia, Scotch laburnum, and Chinese wisteria. As expected, medium EC was highest with the higher fertilizer rate and with decreasing LF. However, the highest EC we found, 2.6
$\mathrm{dS} \cdot \mathrm{m}^{-1}$, was considerably less than the EC of the medium of florist crops treated with $0 \mathrm{LF}$ and $21.4 \mathrm{~mol} \mathrm{~N} / \mathrm{m}^{3}\left(\approx 7 \mathrm{dS} \cdot \mathrm{m}^{-1}\right)(\mathrm{Ku}$ and Hershey, 1991, 1992). Maintaining a low LF with a fertilizer solution containing $>10.7 \mathrm{~mol}$ $\mathrm{N} / \mathrm{m}^{3}$ might have reduced growth of the species we studied by increasing the EC of the medium above a critical level. However, plants treated with $10.7 \mathrm{~mol} \mathrm{~N} / \mathrm{m}^{3}$ appeared vigorous and healthy, and the absence of nodules suggests these plants were not deficient in $\mathrm{N}$. Therefore, applying solutions with $>10.7 \mathrm{~mol}$ $\mathrm{N} / \mathrm{m}^{3}$ might decrease growth at a low LF but not increase growth at a high LF beyond what we achieved. Future studies should define optimal $\mathrm{N}$ levels for these species at varying LF. Among plants provided $3.6 \mathrm{~mol} \mathrm{~N} / \mathrm{m}^{3}$, the similarity of the EC of the medium at the different LF suggests the plants acquired as much $\mathrm{N}$ from the medium as possible. The small size and extensive root nodulation of these plants indicate they were deficient in $\mathrm{N}$, which may explain the lack of an LF effect on growth.

\section{Literature Cited}

Batzli, J.M., W.R. Graves, and P. van Berkum. 1992. Isolation and characterization of rhizobia effective with Maackia amurensis. J. Amer. Soc. Hort. Sci. 117:612-616.

Bunt, A.C. 1988. Media and mixes for containergrown crops. UnWin Hyman, Boston.

Ku, C.S.M. and D.R. Hershey. 1991. Leachate electrical conductivity and growth of potted poinsettia with leaching fractions of 0 to 0.4 . J. Amer. Soc. Hort. Sci. 116:802-806.

Ku, C.S.M. and D.R. Hershey. 1992. Leachate electrical conductivity and growth of potted geranium with leaching fractions of 0 to 0.4 . J. Amer. Soc. Hort. Sci. 117:893-897.

Yelanich, M.V. and J.A. Biernbaum. 1990. Effect of fertilizer concentration and method of application on media nutrient content, nitrogen runoff and growth of Euphorbia pulcherrima ' $\mathrm{V}-14$ Glory'. Acta Hort. 272:185-189.

Yelanich, M.V. and J.A. Biernbaum. 1993. Rootmedium nutrient concentration and growth of poinsettia at three fertilizer concentrations and four leaching fractions. J. Amer. Soc. Hort. Sci. 118:771-776. 